\title{
Performances of the Mortar Made with Roller Steel Slag as Aggregate
}

\author{
Wei Chen ${ }^{1, \mathrm{a} *}$, Zhichun $\mathrm{Hu}^{2, \mathrm{~b}}$, Shoucang $\mathrm{Wu}^{3, \mathrm{c}}$ \\ ${ }^{1}$ MCC Bao Steel Technology Services Co., Ltd, Shanghai 200941, China \\ ${ }^{2}$ MCC Bao Steel Technology Services Co., Ltd, Shanghai 200941, China \\ ${ }^{3}$ MCC Bao Steel Technology Services Co., Ltd, Shanghai 200941, China \\ achenwei94129@sohu.com, 라_huzhichun@sina.com, 'shoucang66@163.com
}

Keywords: Roller steel slag, Mortar, Aggregate, Performance

Abstract. The roller steel slag has many advantages due to the special process can be used as sand in commercial mortar. The parameters of the slag from MCC Baogang Steel Technology Services Co., Ltd were researched, and with 20 60 vol. \% slag replaced for sand, six strength grade mortars were prepared. The results show that the workability and soundness can meet the standard; the compressive strength of the mortars was improved with the dosage of the slag increasing.

\section{Introduction}

Nowadays, the production and application of the commercial mortar is a new popularized technology in China. In order to protect the environment against the pollution and reduce the cost of the commercial mortar, some industrial solid wastes including steel slag used as aggregate in the mortar [1].

The procedures for the steel slag include hot splashing process, converter process and roller process. In three types of the slag, the roller steel slag with some advantages, such as the lower content of free calcium oxide $(f-\mathrm{CaO})$, better grain shape and gradation, higher strength [2], is suitable for the aggregate in the commercial mortar.

In this work, the parameters of the roller steel slag from MCC Baogang Steel Technology Services Co., Ltd were tested, and the performances of the mortars with different replacement ratio for sand were researched.

\section{Experimental}

The roller steel slag was supplied by MCC Baogang Steel Technology Services Co., Ltd, the apparent density was $3260 \mathrm{~kg} / \mathrm{m}^{3}$, the bulk density was $1940 \mathrm{~kg} / \mathrm{m}^{3}$ and the modulus fineness was 3.53. The Ordinary Portland Cement (OPC) 42.5 were obtained from Shaanxi Shengwei Cement (Group) Co., Ltd and the mechanical properties according to Chinese standard GB175-2007 were listed in Table 1. The two grade fly ash was obtained from Shaanxi Weihe Power Co., Ltd. The standard sand was obtained from Xiamen ISO standard sand Co., Ltd.

Table 1 the mechanical properties of the cement

\begin{tabular}{cccc}
\hline \multicolumn{2}{c}{ Compressive strength $(\mathrm{MPa})$} & \multicolumn{2}{c}{ Banding strength (MPa) } \\
\hline $3 \mathrm{~d}$ & $28 \mathrm{~d}$ & $3 \mathrm{~d}$ & $28 \mathrm{~d}$ \\
26.0 & 47.0 & 6.0 & 9.3 \\
\hline
\end{tabular}

Phase composition of the steel slag was investigated by means of X-ray diffraction analysis with

a Rigaku X-ray Diffract meter model D/MAX-3C with $\mathrm{Cu} K \alpha$ radiation. Furthermore, The 
lithofacies was performed with a polarizing microscope.

The compositions of the M30, M25, M20, M15, M10 and M5 mortars were designed according to Chinese standard JGJ/T 98-2010 [3] and listed in Table 2. In the compositions, the replacement ratios of the slag for standard sand were $20 \mathrm{vol} . \%, 40$ vol. $\%$ and $60 \mathrm{vol} . \%$, respectively.

Table 2 Composition of the mortars containing the roller steel slag

\begin{tabular}{|c|c|c|c|c|c|c|c|}
\hline \multirow[t]{2}{*}{ No. } & \multirow{2}{*}{$\begin{array}{l}\text { Strength } \\
\text { grade }\end{array}$} & \multirow{2}{*}{$\begin{array}{c}\text { Dosage of } \\
\text { slag (vol. \%) }\end{array}$} & \multicolumn{5}{|c|}{ Composition $\left(\mathrm{kg} / \mathrm{m}^{3}\right)$} \\
\hline & & & Cement & Fly ash & Sand & Slag & Water \\
\hline 1 & M30 & 0 & 455 & 0 & 1450 & 0 & 270 \\
\hline 2 & & 20 & 455 & 0 & 1160 & 374 & 270 \\
\hline 3 & & 40 & 455 & 0 & 870 & 748 & 260 \\
\hline 4 & & 60 & 455 & 0 & 580 & 1122 & 250 \\
\hline 5 & M25 & 0 & 385 & 0 & 1450 & 0 & 250 \\
\hline 6 & & 20 & 385 & 0 & 1160 & 374 & 250 \\
\hline 7 & & 40 & 385 & 0 & 870 & 748 & 250 \\
\hline 8 & & 60 & 385 & 0 & 580 & 1122 & 250 \\
\hline 9 & M20 & 0 & 370 & 0 & 1500 & 0 & 260 \\
\hline 10 & & 20 & 370 & 0 & 1200 & 387 & 250 \\
\hline 11 & & 40 & 370 & 0 & 900 & 774 & 250 \\
\hline 12 & & 60 & 370 & 0 & 600 & 1161 & 250 \\
\hline 13 & M15 & 0 & 264 & 66 & 1500 & 0 & 260 \\
\hline 14 & & 20 & 264 & 66 & 1200 & 387 & 250 \\
\hline 15 & & 40 & 264 & 66 & 900 & 774 & 250 \\
\hline 16 & & 60 & 264 & 66 & 600 & 1161 & 250 \\
\hline 17 & M10 & 0 & 240 & 60 & 1500 & 0 & 250 \\
\hline 18 & & 20 & 240 & 60 & 1200 & 387 & 250 \\
\hline 19 & & 40 & 240 & 60 & 900 & 774 & 250 \\
\hline 20 & & 60 & 240 & 60 & 600 & 1161 & 250 \\
\hline 21 & M5 & 0 & 192 & 48 & 1500 & 0 & 250 \\
\hline 22 & & 20 & 192 & 48 & 1200 & 387 & 250 \\
\hline 23 & & 40 & 192 & 48 & 900 & 774 & 250 \\
\hline 24 & & 60 & 192 & 48 & 600 & 1161 & 250 \\
\hline
\end{tabular}

The soundness of the mortars was tested by the boiling process for $3 \mathrm{~h}$. The compressive strength of the mortars was tested according to Chinese standard JGJ/T 70-2009 [4].

\section{Results and Discussion}

Phase composition. The phase composition of the roller steel slag was tested by XRD and the lithofacies method, and the resulted were shown in Fig. 1 and Fig. 2. From Fig. 1, the main phases in the slag were tricalcium silicate $\left(\mathrm{C}_{3} \mathrm{~S}\right)$, dicalcium silicate $\left(\mathrm{C}_{2} \mathrm{~S}\right)$, which indicated that the slag can participate the hydration reaction owing to the certain activity of $\mathrm{C}_{3} \mathrm{~S}$ and $\mathrm{C}_{2} \mathrm{~S}$. The slag also contained a certain amount of pure Fe, hematite $\left(\mathrm{Fe}_{2} \mathrm{O}_{3}\right)$, magnetite $\left(\mathrm{Fe}_{3} \mathrm{O}_{4}\right)$ and calcium hydroxide $\left(\mathrm{Ca}(\mathrm{OH})_{2}\right)$, but it contained almost no $f-\mathrm{CaO}$. 


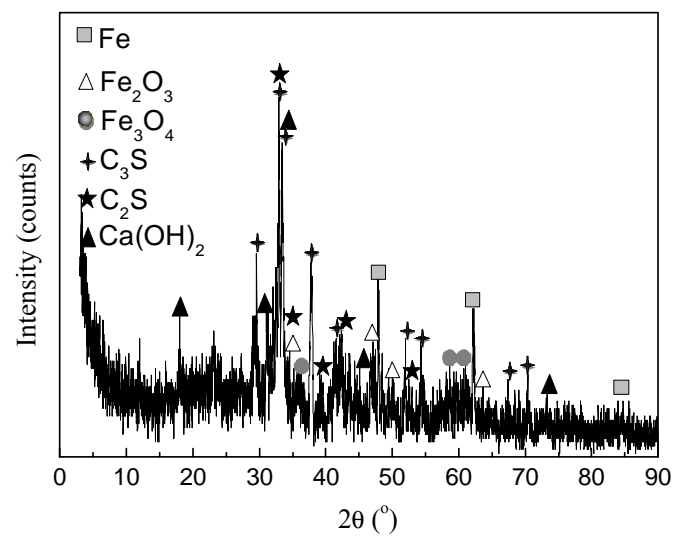

Fig. 1 the XRD results of the roller steel slag

The lithofacies analysis results were shown in Fig. 2. From Fig. 2(a), $\mathrm{C}_{3} \mathrm{~S}$ and $\mathrm{C}_{2} \mathrm{~S}$ were symbiotic together and there was a certain degree of crystallization. Fig. 2(b) showed that $\mathrm{Fe}_{2} \mathrm{O}_{3}$ was embedded in the internal of $\mathrm{C}_{3} \mathrm{~S}$. The lithofacies results matched with the results of XRD.
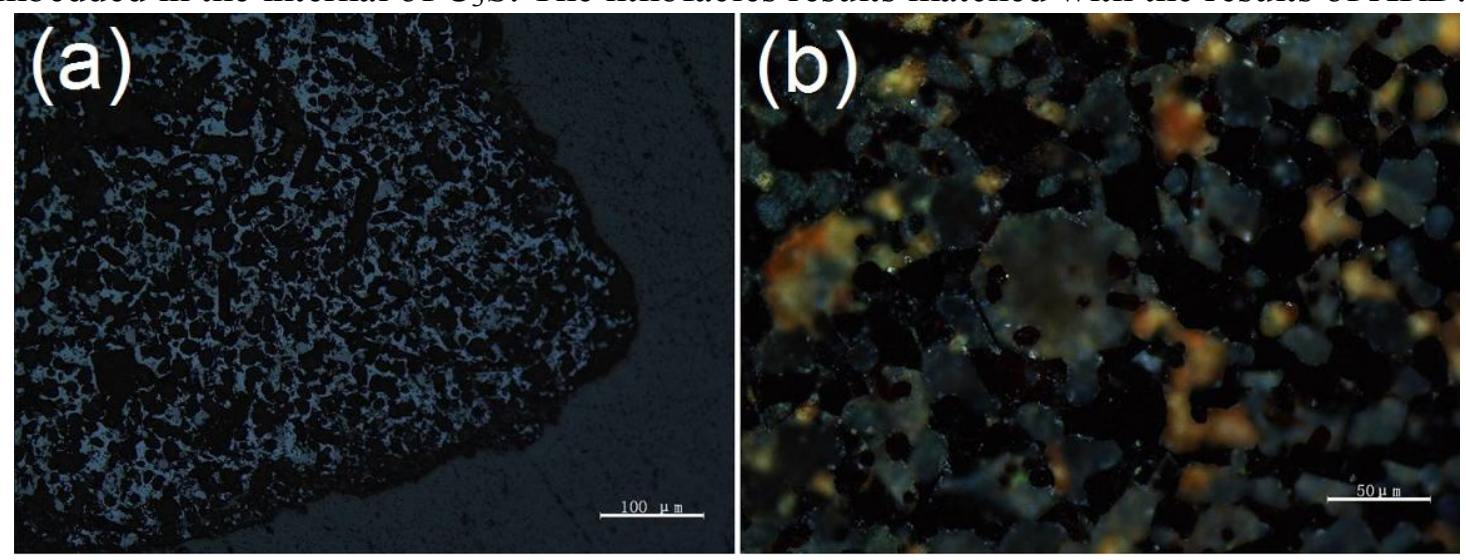

Fig. 2 the lithofacies analysis results of the roller steel slag

Workability, soundness and compressive strength of the mortars. The results of the workability, soundness and compressive strength of the mortars were listed in Table 3. From Table 3, the workability and the soundness with the boiling process both meet the construction requirements and standards. 
Table 3 the results of soundness, workability and compressive strength of the mortars

\begin{tabular}{|c|c|c|c|c|c|c|}
\hline \multirow{2}{*}{ No. } & \multirow{2}{*}{$\begin{array}{l}\text { Strength } \\
\text { grade }\end{array}$} & \multirow{2}{*}{$\begin{array}{l}\text { Dosage of slag } \\
\text { (vol. \%) }\end{array}$} & \multirow{2}{*}{ Workability } & \multirow{2}{*}{$\begin{array}{l}\text { Soundness with } \\
\text { boiling process }\end{array}$} & \multicolumn{2}{|c|}{ Compressive strength (MPa) } \\
\hline & & & & & $7 \mathrm{~d}$ & $28 \mathrm{~d}$ \\
\hline 1 & M30 & 0 & Good & Up to standard & 24.0 & 36.0 \\
\hline 2 & & 20 & Good & Up to standard & 24.8 & 37.4 \\
\hline 3 & & 40 & Good & Up to standard & 34.2 & 41.6 \\
\hline 4 & & 60 & Good & Up to standard & 36.2 & 42.6 \\
\hline 5 & M25 & 0 & Good & Up to standard & 18.8 & 22.0 \\
\hline 6 & & 20 & Good & Up to standard & 21.4 & 24.0 \\
\hline 7 & & 40 & Good & Up to standard & 22.2 & 28.6 \\
\hline 8 & & 60 & Good & Up to standard & 21.0 & 29.2 \\
\hline 9 & M20 & 0 & Good & Up to standard & 16.8 & 22.8 \\
\hline 10 & & 20 & Good & Up to standard & 17.8 & 25.4 \\
\hline 11 & & 40 & Good & Up to standard & 18.8 & 26.8 \\
\hline 12 & & 60 & Good & Up to standard & 22.0 & 27.6 \\
\hline 13 & M15 & 0 & Good & Up to standard & 9.6 & 17.4 \\
\hline 14 & & 20 & Good & Up to standard & 9.4 & 17.8 \\
\hline 15 & & 40 & Good & Up to standard & 9.4 & 18.4 \\
\hline 16 & & 60 & Good & Up to standard & 9.0 & 18.8 \\
\hline 17 & M10 & 0 & Good & Up to standard & 7.8 & 12.0 \\
\hline 18 & & 20 & Good & Up to standard & 8.0 & 13.2 \\
\hline 19 & & 40 & Good & Up to standard & 8.0 & 13.4 \\
\hline 20 & & 60 & Good & Up to standard & 8.6 & 13.8 \\
\hline 21 & M5 & 0 & Good & Up to standard & 3.0 & 6.0 \\
\hline 22 & & 20 & Good & Up to standard & 3.0 & 6.4 \\
\hline 23 & & 40 & Good & Up to standard & 3.2 & 7.2 \\
\hline 24 & & 60 & Good & Up to standard & 3.8 & 7.4 \\
\hline
\end{tabular}

The compressive strength of the mortars was tested at $7 \mathrm{~d}$ and $28 \mathrm{~d}$. From the results, all of the compressive strength at $28 \mathrm{~d}$ can meet the strength grade and 1.2 times the strength standard values, which indicated that the roller steel slag does not reduce the strength of the mortars and can used in all of mortars with different strength grade.

Furthermore, the compressive strength of the mortars was improved with the dosage of the slag increasing. The causes of the above phenomena may be that $\mathrm{C}_{3} \mathrm{~S}$ and $\mathrm{C}_{2} \mathrm{~S}$ in the slag participated in the hydration reaction and improved the interfacial strength of slag and cement paste.

\section{Conclusion}

The phases in the roller steel slag were tricalcium silicate $\left(C_{3} S\right)$, dicalcium silicate $\left(C_{2} S\right)$, pure Fe, hematite $\left(\mathrm{Fe}_{2} \mathrm{O}_{3}\right)$, magnetite $\left(\mathrm{Fe}_{3} \mathrm{O}_{4}\right)$ and calcium hydroxide $\left(\mathrm{Ca}(\mathrm{OH})_{2}\right)$. The mortars from strength grade M30 to M5 all can be prepared with 20 60 vol. \% slag replaced for sand, both the workability and soundness can meet the standard. Furthermore, the compressive strength of the mortars was improved with the dosage of the slag increasing. 


\section{References}

[1]H. Higashiyama, M. Sappakittipakom, M. Mizukoshi, O. Takahashi. Efficiency of ground granulated blast-furnace slag replacement in ceramic waste aggregate mortar. Cement and Concrete Composites. 49(2014) 43-49.

[2]G. Yang, Y.Q. Wang, H.L. Wang, et al. Test and analysis of influencing factors on the permeability coefficient of steel slag permeable concrete. Baogang Technical Research. 5(2011) 24-27.

[3] Specification for mix proportion design of masonry mortar. JGJ/T 98-2010.

[4] Standard for test method of basic properties of construction mortar. JGJ/T 70-2009. 